\title{
GENÓTIPOS DE MILHO COM ALTA CAPACIDADE PARA EMBRIOGÊNESE SOMÁTICA E REGENERAÇÃO DE PLANTAS OBTIDOS A PARTIR DE CALOS'
}

\author{
Janay Almeida dos Santos-Serejo ${ }^{2,4}$; Margarida L. R. de Aguiar-Perecin ${ }^{3 *}$ \\ ${ }^{2}$ Pós-Graduanda do Depto. de Genética - USP/ESALQ. \\ ${ }^{3}$ Depto. Genética - USP/ESALQ, C.P. 83 - CEP: 13418-900 - Piracicaba, SP. \\ ${ }^{4}$ Bolsista CNPq. \\ *Autor Correspondente <mlrapere@carpa.ciagri.usp.br>
}

\begin{abstract}
RESUMO: Como parte de um programa que visa a seleção de linhagens adaptadas a regiões tropicais, com a capacidade para regenerar plantas a partir de calos embriogênicos de curta duração, foram investigadas três linhagens obtidas a partir de uma variedade de milho tipo flint, e seus respectivos híbridos. As culturas foram obtidas a partir de embriões imaturos inoculados em meio N6 suplementado com 1,5 $\mathrm{mg} \mathrm{L}^{-1}$ de 2,4-D e prolina $12 \mathrm{mM}$. A frequência de calos embriogênicos 45 dias após o início da cultura foi semelhante aos melhores genótipos descritos na literatura (83-99\%), refletindo a alta qualidade dos genótipos testados para 0 estabelecimento de culturas de curta duração. O número médio de plantas férteis regeneradas em culturas com 2-3 meses de idade variou de 2 a 8,15 por calo, destacando-se os híbridos 13342/5 x 13342/2 e 132331/ $1 \times 13342 / 5$. Os resultados mostram que estes genótipos são promissores para utilização em programas envolvendo transformação de plantas e propagação de genótipos.
\end{abstract}

Palavras-chave: milho, cultura de tecido, embriogênese somática, regeneração

\section{GENOTYPES WITH HIGH SOMATIC EMBRYOGENESIS AND PLANT REGENERATION CAPACITY OBTAINED FROM TISSUE CULTURE}

\begin{abstract}
As part of a breeding program to select tropical maize lines which are able to regenerate plants from embryogenic calli, three lines obtained from a flint maize variety, and their respective hybrids, have been investigated. Short-term tissue cultures were obtained from immature embryos inoculated on N6 medium suplemented with $1.5 \mathrm{mg} \mathrm{L}^{-1} 2,4-\mathrm{D}$ and $12 \mathrm{mM}$ L-proline. The frequency of 45 day-old embryogenic calli was similar to those of the best genotypes described in the literature (83-99\%), reflecting the high quality of the genotypes evaluated to estabilish short-term tissue cultures. The average number of fertile regenerated plants in 2-3 month-old cultures ranged from 2 to 8.15 per callus, and the hybrids $13342 / 5 \times 13342 / 2$ and $132331 / 1 \times$ $13342 / 5$ showed the bestg performance. The results show that these genotypes may be used in programs involving plant transformation and genotype propagation.

Key words: maize, tissue culture, somatic embryogenesis, regeneration
\end{abstract}

\section{INTRODUÇÃO}

Nos últimos anos tem crescido o interesse na utilização de culturas embriogênicas de milho visando a produção de plantas geneticamente transformadas (revisão em Armstrong, 1999). Os primeiros relatos de produção de milho transgênico fértil ocorreram no início desta década (Gordom-Kamm et al., 1990; Fromm et al., 1990; Walters et al., 1992). Desde então, genes cuja exploração através de métodos tradicionais de melhoramento é inviável, têm sido introduzidos via transformação e mostrado capacidade de conferir resistência a importantes pragas e doenças, bem como tolerância a herbicidas (Koziel et al., 1993; Murry et al., 1993; Armstrong et al. 1995). Entretanto, a produção de plantas geneticamente transformadas depende da integração do gene exógeno na célula alvo e da eficiência com que plantas são regeneradas a partir destas células. Até o presente, os sistemas mais utilizados para transformação em milho têm sido a cultura de calos embriogênicos, ou mesmo o cultivo direto de embriões imaturos ou pré-cultivados (Armstrong, 1999).

Várias linhagens e híbridos adaptados a regiões de clima temperado têm sido utilizados para indução de culturas de calos, porém, a regeneração de plantas a partir de calos embriogênicos tem sido obtida eficientemente a partir de poucos genótipos, destacando-se a linhagem A188, que apresenta pouco valor agronômico mas é muito superior a outras linhagens de milho em sua capacidade para regenerar plantas a partir de calos embriogênicos (Green \& Phillips, 1975; Lee \& Phillips, 1987; Armstrong \& Phillips, 1988; Armstrong et al., 1992). Alguns genótipos adaptados a regiões tropicais e subtropicais com capacidade para produção de calos embriogênicos têm sido relatados (Prioli \& Silva, 1989; Furini \& Jewell, 1994; Bohorova et al., 1995; Fluminhan \& Aguiar-Perecin, 1998). Entre quatro famílias de linhagens derivadas de uma variedade de milho tipo flint de origem tropical (Jac-Duro, 
Sementes Agroceres, Brasil), destacou-se uma que apresentou alta capacidade de produção de calos tipo II, isto é, friável e altamente embriogênico (Fluminhan, 1992; Fluminhan \& Aguiar-Perecin, 1998). Em outro experimento, verificou-se que uma cultura embriogênica de longa duração, derivada de uma determinada linhagem desta família e que apresentava estabilidade cromossômica, regenerava plantas férteis (Santos, 1995; Santos \& AguiarPerecin, 1995). Num estudo posterior utilizando três linhagens da família 1-3 e respectivos híbridos, Gardingo (1998) constatou que com a introdução de modificações no meio de cultura, esses genótipos apresentavam resposta embriogênica superior às observadas entre linhagens relacionadas com esses genótipos, por Fluminhan \& Aguiar-Perecin (1998).

No presente trabalho são relatados os resultados de uma avaliação da capacidade de regeneração de plantas a partir de culturas de curta duração (cerca de 23 meses de cultivo) derivadas dos mesmos genótipos estudados por Gardingo (1998).

\section{MATERIAL E MÉTODOS}

As linhagens utilizadas são derivadas de uma variedade de milho tipo flint de origem tropical (Jac-Duro, Sementes Agroceres, Brasil), pertencentes à família designada 1-3 que num estudo anterior apresentou resposta altamente embriogênica e diferentes frequências de instabilidade mitótica (Fluminhan \& Aguiar-Perecin, 1998). A TABELA 1 apresenta as linhagens e respectivos híbridos usados no presente estudo, bem como a descrição de seus marcadores cromossômicos (knobs heterocromáticos), mapeados em estudos citogenéticos anteriores, que visavam a investigação da estabilidade cromossômica desta culturas (Aguiar-Perecin \& Decico, 1988; Fluminhan et al., 1996), e que consideramos como descritores importantes destas linhagens.

As culturas foram iniciadas a partir de embriões imaturos (1,5 - 2,0 mm), removidos de espigas 12-14 dias após a polinização, e inoculados em placas de Petri

TABELA 1 - Linhagens e respectivos híbridos usados no presente estudo, bem como a descrição de seus marcadores cromossômicos (knobs heterocromáticos).

\begin{tabular}{lcccccccc}
\hline Genótipo & \multicolumn{7}{c}{$\mathrm{Knob}^{*}$} \\
\cline { 2 - 8 } & $\mathrm{K} 3 \mathrm{~L}$ & $\mathrm{~K}^{\prime} \mathrm{L}_{2}$ & $\mathrm{~K} 6 \mathrm{~L}_{3}$ & $\mathrm{~K} 7 \mathrm{~S}$ & $\mathrm{~K} 7 \mathrm{~L}$ & $8 \mathrm{~L}_{1}$ & $\mathrm{~K} 9 \mathrm{~S}$ \\
\hline $13342 / 2$ & ++ & ++ & ++ & ++ & ++ & ++ & 00 \\
$13342 / 5$ & 00 & ++ & ++ & ++ & ++ & ++ & 00 \\
$132331 / 1$ & 00 & ++ & ++ & ++ & ++ & ++ & ++ \\
$13342 / 2 \times 13342 / 5$ & +0 & ++ & ++ & ++ & ++ & ++ & 00 \\
$13342 / 2 \times 132331 / 1$ & +0 & ++ & ++ & ++ & ++ & ++ & +0 \\
$132331 / 1 \times 13342 / 5$ & 00 & ++ & ++ & ++ & ++ & ++ & +0 \\
\hline
\end{tabular}

${ }^{*} \mathrm{~K}$, knob; o número se refere ao cromossomo que possui o knob; S, braço curto; L, braço longo. contendo meio N6 (Chu et al., 1975) com componentes orgânicos de acordo com Fluminhan et al. (1996) e suplementado com $1,5 \mathrm{mg} \mathrm{L}^{-1}$ de 2,4-D e prolina $12 \mathrm{mM}$. $\mathrm{O} \mathrm{pH}$ foi ajustado para 5,8 antes da autoclavagem e o meio foi solidificado com agar a $8 \%$. Aproximadamente 60 embriões por espiga e no mínimo duas espigas por genótipo foram utilizados. As culturas foram mantidas no escuro a $28^{\circ} \mathrm{C}$ e subcultivadas a cada $15-21$ dias.

A frequência de embriogênese somática foi avaliada 45 dias após o inicio da cultura, e está expressa como percentagem de calos embriogênicos em relação ao número de embriões inoculados.

A regeneração de plantas foi realizada 2-3 meses após o início da cultura, pela transferência de oito calos embriogênicos por genótipo para placas contendo meio N6 suplementado com $0,5 \mathrm{mg} \mathrm{L}^{-1}$ de 2,4-D (quatro calos por placa), onde permaneceram por 3-5 dias no escuro e 710 dias sob luz (fotoperíodo 16:8 horas). Em seguida, foram transferidos para placas contendo meio MS (Murashige e Skoog, 1962) sem 2,4-D, até desenvolverem coleoptile e raízes (14-20 dias), sendo então transferidos para frascos contendo meio MS sem hormônio. As plântulas com sistema radicular bem desenvolvido foram transplantadas para potes plásticos contendo uma mistura de terra e vermiculite (1:1) e mantidas durante 1 a 3 dias em casa-de-vegetação a $28-30{ }^{\circ} \mathrm{C}$. Em seguida, foram transferidas para vasos de cerâmica e finalmente para sacos plásticos, em casa de vegetação.

\section{RESULTADOS E DISCUSSÃO}

O presente estudo faz parte de um programa que visa a seleção de linhagens adaptadas a regiões tropicais com capacidade de formar calos altamente embriogênicos, e de regenerar plantas férteis que apresentem estabilidade cromossômica. Nesta análise foi investigada a capacidade de determinadas linhagens e respectivos híbridos regenerarem plantas a partir de culturas de calos de curta duração (2-3 meses de cultivo), usando o protocolo descrito por Fluminhan (1992) e Santos (1995), com modificações.

Os genótipos utilizados foram os mesmos investigados por Gardingo (1998) para avaliação da resposta embriogênica em culturas de calos de curta duração (45 dias) e de longa duração (6 e 12 meses). A linhagem 13342/2 foi utilizada em substituição à 13342/1, avaliada por Gardingo (1998), ambas com a mesma composição de knobs (TABELA 1).

Em todos os genótipos analisados foi observada a formação de embriões somáticos sobre a superfície dos calos duas semanas após a inoculação (Figura 1). Calos tipo II, friáveis e altamente embriogênicos, semelhantes aos descritos por Armstrong \& Green (1985), foram observados nas linhagens $13342 / 5$ e $132331 / 1$, e no respectivo híbrido (Figuras 1b, 1c, 2a e 3a). Na linhagem $13342 / 2$ de uma maneira geral, foram observados calos de aparência mais compacta, apresentando regiões 
embriogênicas (Figura 1a). Esta característica foi observada também nos híbridos originados de cruzamentos que envolveram esta linhagem (Figuras $2 b$ e 3b). A resposta observada na linhagem 13342/2 é semelhante aos resultados obtidos para a linhagem 13342/ 1 nos experimentos de Gardingo (1998).

A frequência de embriogênese somática aos 45 dias variou de $83,46 \%$ no híbrido $13342 / 2 \times 13342 / 5$ a $99,22 \%$ na linhagem 13342/5 (TABELA 2), confirmando a superioridade destes genótipos observada em experimentos anteriores (Fluminhan \& Aguiar-Perecin, 1998; Gardingo, 1998). Os resultados obtidos são comparáveis àqueles observados para os melhores genótipos tropicais descritos na literatura (Bohorova et al., 1995; Prioli \& Silva, 1989; Hodges et al., 1986), e superiores aos encontrados para genótipos de origem tropical e subtropical testados por Furini \& Jewell (1994).

A correlação entre genótipo e resposta embriogênica em culturas de calos iniciadas a partir de embriões imaturos tem sido bem documentada (Green \& Phillips, 1975; Vasil et al., 1984; Tomes \& Smith, 1985; Kamo \& Hodges, 1986). Poucos genótipos de milho são capazes de formar calos tipo II, o que sugere a ocorrência de um controle genético na determinação do tipo de resposta ao cultivo in vitro (Tomes \& Smith, 1985; Henry et al., 1994). Entretanto, na literatura existem poucos relatos sobre os genes envolvidos na embriogênese somática e regeneração de plantas de milho. Wan et al. (1992) identificaram, através da análise de RFLP, seis regiões cromossômicas envolvidas na resposta ao cultivo in vitro. Armstrong et al. (1992) verificaram que a região cromossômica mais crítica para a formação de calos encontrava-se no braço longo do cromossomo 9. Portanto, as linhagens presentemente estudadas representam um material interessante para futuras investigações do controle genético da resposta ao cultivo in vitro. Analisando genótipos tropicais, Prioli \& Silva (1989) encontraram alta frequência de embriogênese somática em linhagens da raça Cateto, que é um dos componentes da variedade usada como fonte das linhagens utilizadas no presente estudo. Portanto, estas linhagens podem ter acumulado segmentos cromossômicos derivados da raça Cateto importantes para a resposta embriogênica.
A regeneração de plantas foi realizada 2-3 meses após o início da cultura, selecionando-se oito calos por genótipo (quatro calos por placa). A manutenção do calo com embriões somáticos em sua superfície em meio contendo $0,5 \mathrm{mg} \mathrm{L}^{-1}$ de 2,4-D, no escuro e depois sob luz, foi importante para o desenvolvimento dos embriões menores e permitiu a sincronização dos embriões no processo de regeneração de plantas. Alguns pontos no processo foram críticos, como por exemplo, a passagem dos embriões germinados para frascos, onde a densidade de embriões é importante. Foram obtidos bons resultados com 8-15 embriões germinados por frasco. Outra etapa importante refere-se à aclimatação das plantas em casa de vegetação, sendo que o grau de umidade, temperatura, época do ano e intensidade de luz são pontos que ainda devem ser melhorados para obtenção de maior rendimento de regenerantes a partir dos genótipos investigados.

As frequências de plantas regeneradas a partir dos genótipos estudados estão expressas na TABELA 2. O número médio de regenerantes variou de 2 a 8,15 por calo entre os genótipos analisados. O híbrido 13342/2 x 13342/ 5 apresentou o maior número de plantas regeneradas, sendo que 19 produziram espigas. O maior rendimento de plantas por calo foi obtido no híbrido 132331/1 x 13342/5, o qual também apresentou maior frequência de calos embriogênicos e maior estabilidade cromossômica no estudo realizado por Gardingo (1998).

A média de plantas regeneradas por calo pode ser considerada alta (TABELA 2), sendo semelhante aos resultados obtidos para a linhagem A188 por Hodges et al. (1986). Os resultados são, no entanto, superiores aos obtidos por Furini \& Jewell (1994) em genótipos tropicais e subtropicais, e por Hodges et al. (1986) em diversas linhagens e em híbridos obtidos através do cruzamento destas linhagens com a linhagem A188.

Do total de 185 plantas regeneradas, 48 foram utilizadas para análise citológica. A análise mitótica e meiótica das plantas regeneradas mostrou estabilidade cromossômica em todos os genótipos (Santos-Serejo, 1999). Das plantas restantes, 70 (aproximadamente 50\%) produziram espigas com sementes, variando em média de 35,7 sementes por espiga no genótipo 132331/1 x 13342/ 5 a 73,5 no genótipo 13342/2 x 132331/1 (TABELA 2). Algumas plantas apresentaram inflorescência masculina
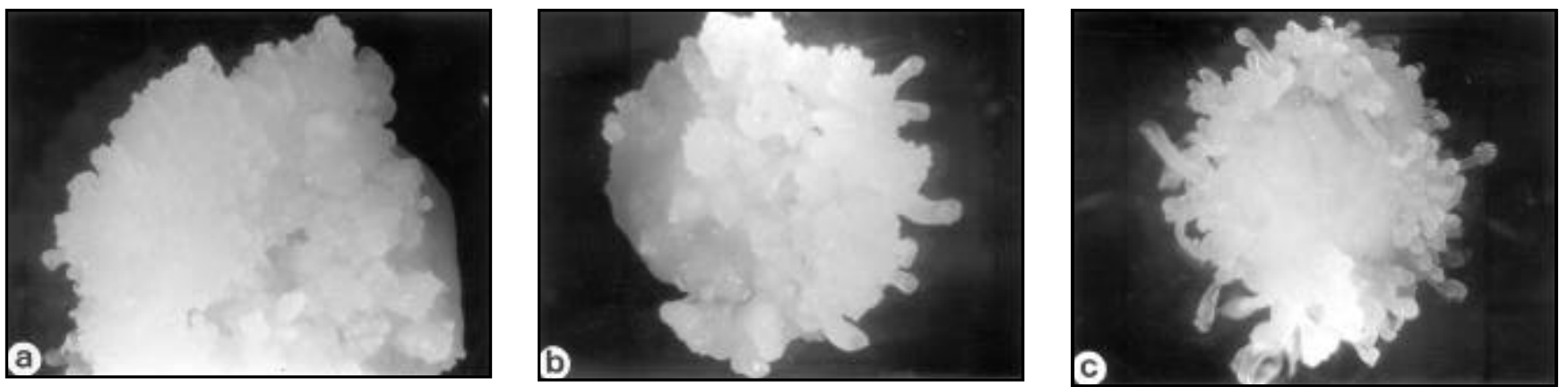

Figura 1 - Calos embriogênicos com 45 dias de cultivo, dos genótipos a) 13342/2; b) 13342/5; c) 132331/1. O genótipo 13342/2 tem tendência de formar calos mais compactos. Aumento de 9x. 

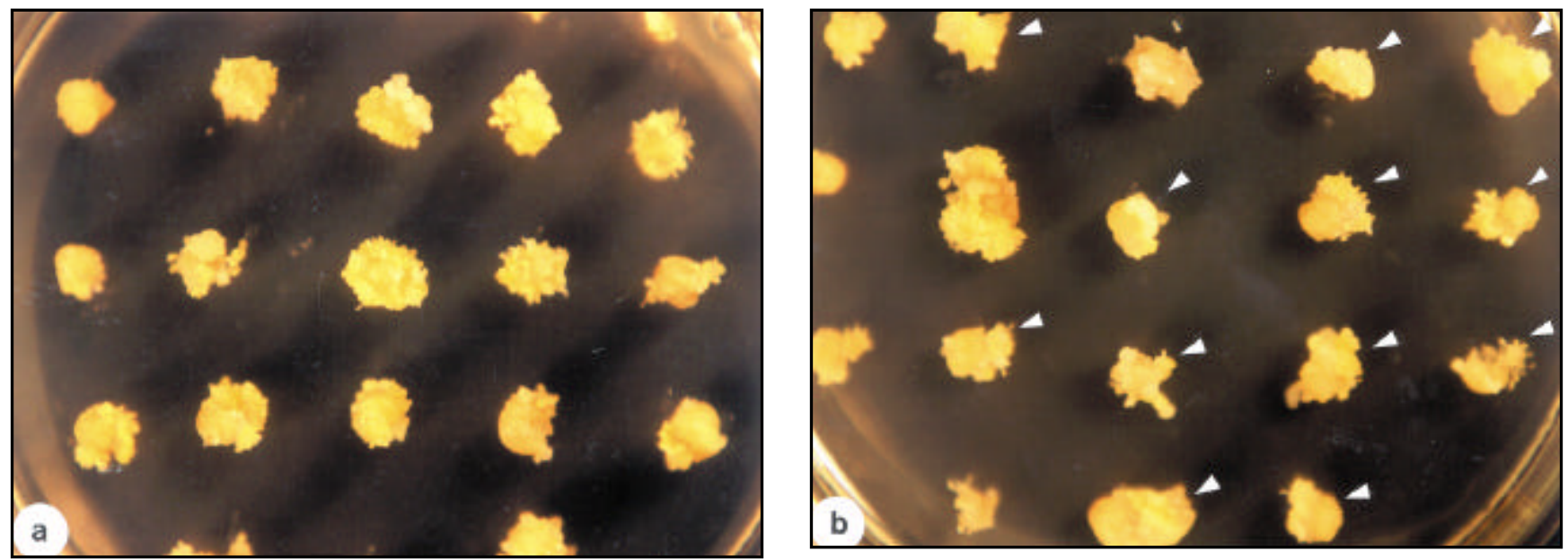

Figura 2 - Placas de culturas com 45 dias de cultivo. a) Linhagem 132331/1, altamente embriogênica; b) Híbrido 132331/1 x 13342/2, apresentando vários calos compactos (setas), típicos do genótipo 13342/2. Aumento de 0,8x.
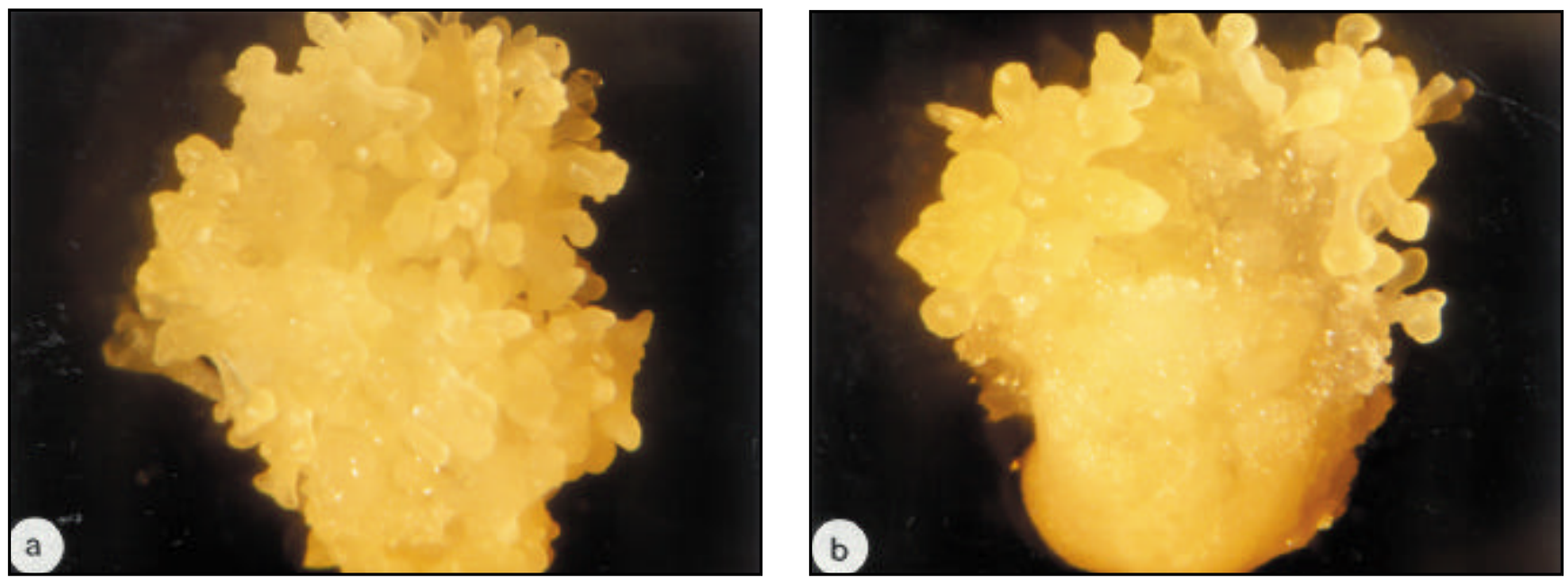

Figura 3 - Calos embriogênicos com 45 dias de cultivo, dos genótipos a) 132331/1 x 13342/5, altamente embriogênico; b) 13342/2 x 132331/1, mais compacto e apresentando regiões embriogênicas. Aumento de 13x.
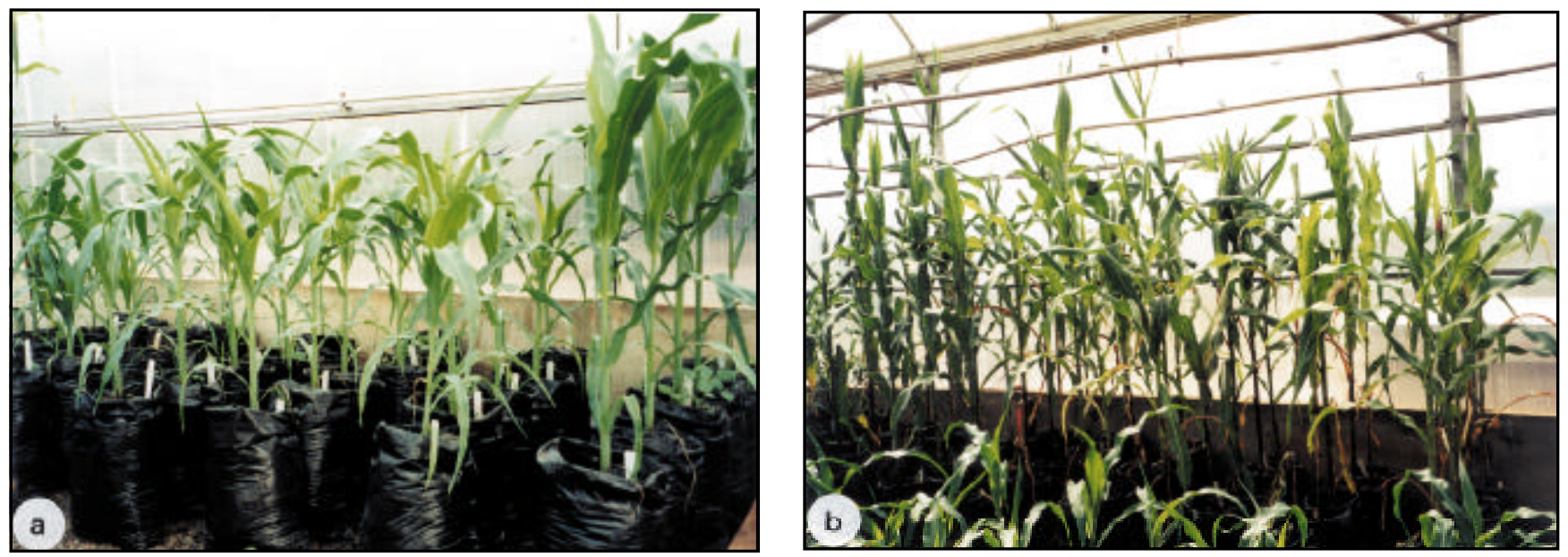

Figura 4 - Plantas regeneradas a partir de culturas com 2-3 meses. a) Linhagem 132331/1; b) Híbrido 132331/1 x 13342/5. 
TABELA 2 - Frequência de calos embriogênicos 45 dias após o início da cultura, número de plantas regeneradas, de espigas produzidas e de sementes por espiga.

\begin{tabular}{|c|c|c|c|c|c|c|c|}
\hline \multirow[t]{2}{*}{ Genótipo } & \multicolumn{2}{|c|}{ Calos embriogênicos } & \multirow[t]{2}{*}{ NCR } & \multicolumn{2}{|c|}{ Plantas regeneradas } & \multirow[t]{2}{*}{ Espigas $^{\dagger}$} & \multirow[t]{2}{*}{$\begin{array}{c}\text { Sementes } \\
\text { por espiga }\end{array}$} \\
\hline & & $\%^{*}$ & & Total & Plantas/calo & & \\
\hline $13342 / 2$ & 85,24 & $(104 / 122)$ & 6 & 34 & 5,67 & 14 & 53,0 \\
\hline $13342 / 5$ & 99,22 & $(128 / 129)$ & 2 & 4 & 2,0 & - & - \\
\hline $132331 / 1$ & 90,53 & $(220 / 243)$ & 7 & 41 & 5,86 & 24 & 44,1 \\
\hline $13342 / 2 \times 13342 / 5$ & 83,46 & $(106 / 127)$ & 7 & 51 & 7,29 & 19 & 59,4 \\
\hline $13342 / 2 \times 132331 / 1$ & 90,27 & $(232 / 257)$ & 4 & 19 & 4,75 & 2 & 73,5 \\
\hline $132331 / 1 \times 13342 / 5$ & 97,54 & $(238 / 244)$ & 5 & 36 & 8,15 & 11 & 35,7 \\
\hline
\end{tabular}

*Entre parêntesis número de calos embriogênicos por número de embriões inoculados.

\#NCR = número de calos que regeneraram plantas. Foram testados oito calos por genótipo.

${ }^{\dagger} N$ ão inclui plantas que foram utilizadas para análise citológica

‡Média das espigas analisadas.

parcialmente feminilizada ou seca, provavelmente devido a estresse fisiológico ocorrido durante a aclimatação. A Figura 4 apresenta plantas regeneradas a partir de culturas com 2-3 meses, derivadas da linhagem 132331/1 e do híbrido 132331/1 x 13342/5.

Os resultados obtidos tornam evidente que as linhagens testadas, constituem genótipos promissores para estudos do controle genético da resposta in vitro, bem como para obtenção de plantas transgênicas.

\section{REFERÊNCIAS BIBLIOGRÁFICAS}

AGUIAR-PERECIN, M.L.R. de; DECICO, J.U. Preliminary results on the segregation of knobs (C-bands) in inbred lines from a flint variety. Maize Genetics Cooperation Newsletter, v.62, p.100, 1988.

ARMSTRONG, C.L. The first decade of maize transformation: a review and future perspective. Maydica, v.44, p.101-109, 1999.

ARMSTRONG, C.L.; GREEN, C.E. Establishment and maintenance of friable, embryogenic maize callus and the involvement of L-proline. Planta, v.164, p.207-214, 1985.

ARMSTRONG, C.L.; PHILLIPS, R.L. Genetic and cytogenetic variation in plants regenerated from organogenic and friable, embryogenic tissue cultures of maize. Crop Science, v.28, p.363-369, 1988

ARMSTRONG, C.L.; ROMERO-SEVERSON, J.; HODGES, T.K. Improved tissue culture response of an elite maize inbred through backcross breeding, and identification of chromosomal regions important for regeneration by RFLP analysis. Theoretical and Applied Genetics, v.84, p.755-762, 1992.

ARMSTRONG, C.L.; PARKER, G.B.; PERSHING, J.C.; BROWN, S.M.; SANDERS, P.R.; DUNCAN, D.R.; STONE, T.; DEAN, D.A.; DEBOER, D.L.; HART, J.; HOWE, A.R.; MORRISH, F.M.; PAJEAU, M.E.; PETERSEN, W.L.; REICH, B.J.; RODRIGUEZ, R.; SANTINO, C.G.; SATO, S.J.; SCHULER, W.; SIMS, S.R.; STEHLING, S.; TAROCHIONE, L.; FROMM, M.E. Field evaluation of European corn borer control in progeny of 173 transgenic corn events expressing na insecticidal protein from Bacillus thurigiensis. Crop Science, v.35, p.550-557, 1995.

BOHOROVA, N.E.; LUNA, B.; BRITO, R.M.; HUERTA, L.D.; HOISINGTON, D.A. Regeneration potential of tropical, subtropical, midaltitude, and highland maize inbreeds. Maydica, v.40, p.275-281, 1995.
CHU, C.C.; WANG, C.C.; SUN, C.S.; HSU, K.C.; YIN, C.Y.; CHU, C.Y.; BI, F.Y. Establishment of an efficient medium for anther culture of rice through comparative experiments on the nitrogen sources. Scientia Sinica, v.16, p.659-688, 1975.

FLUMINHAN, A. Cultivo in vitro de milho (Zea mays) e análise de sua instabilidade mitótica. Piracicaba, 1992. 213p. Dissertação (Mestrado) - Escola Superior de Agricultura "Luiz de Queiroz", Universidade de São Paulo.

FLUMINHAN, A.; AGUIAR-PERECIN M.L.R. Embriogenic response and mitotic instability in callus cultures derived from maize inbred lines differing in heterochromatic knob content of chromosomes. Annals of Botany, v.82, p.569-576, 1998.

FLUMINHAN, A.; AGUIAR-PERECIN M.L.R.; SANTOS, J.A. Evidence for heterochromatin involvement on chromosome breakage in maize callus culture. Annals of Botany, v.78, p.73-81, 1996.

FROMM, M.E.; MORRISH, F.; ARMSTRONG, C.; WILLIAMS, R.; THOMAS, J.; KLEIN, T.M. Inheritance and expression of chimeric genes in the progeny of trangenic maize plants. Biol Technology, v.8, p.833-839, 1990.

FURINI, A.; JEWELL, D.C. Somatic embryogenesis and plant regeneration from immature and mature embryos of tropical and subtropical Zea mays L. genotypes. Maydica, v.39, p.155-164, 1994.

GARDINGO, J.R. Resposta embriogênica e estabilidade cromossômica em calos derivados de linhagens e híbridos de milho (Zea mays L.). Piracicaba, 1998. 125p. Tese (Doutorado) - Escola Superior de Agricultura "Luiz de Queiroz", Universidade de São Paulo.

GORDOM-KAMM, W.J.; SPENCER, T.M.; MANGANO, M.L.; ADAMS, T.R.; DAINES, R.J.; START, W.G.; O'BRIEN, J.V.; CHAMBERS, S.A.; ADAMS JUNIOR, W.R.; WILLETTS, N.G.; RICE, T.B.; MACKEY, C.J.; KRUEGER, R.W.; KAUSCH, A.P.; LEMAUX, P.G. Transformation of maize cells and regeneration of fertile transgenic plants. The Plant Cell, v.2, p.603-618, 1990.

GREEN, C.E.; PHILLIPS, R.L. Plant regeneration from tissue cultures of maize. Crop Science, v.15, p.417-421, 1975.

HENRY, Y.; VAIN, P.; DE BUYSER, J. Genetic analysis of in vitro plant tissue culture responses and regeneration capacities. Euphytica, v.79, p.45-58, 1994.

HODGES, T.K.; KAMO, K.K.; IMBRIE, C.; BECWAR, M.R. Genotype specificity of somatic embryogenesis and regeneration in maize. Bio/Technology, v.4, p.219-223, 1986.

KAMO, K.K.; HODGES, T.K. Establishment and caracterization of long-term embryogenic maize callus and cell suspension cultures. Plant Science, v.45, p.111-117, 1986. 
KOZIEL, M.G.; BELAND, G.L.; BOWAMAN, C.; COROZZI, N.B.; CRENSHAW, R.; CROSSLAND, L.; DAWSON, J.; DESAI, N.; HILL, M.; KADWELL, S.; LAUNIS, K.; LEWIS, K.; MADDOX, D.; McPHERSON, K.; MEGHJI, M.R.; MERLIN, E.; RHODES, R.; WARREN, G.W.; WRIGHT, M.; EVOLA, S.V. Field performance of elite transgenic maize plants expressing na insecticidal protein derived from Bacillus thurigiensis. Biol Technology, v.11, p.194-200, 1993.

LEE, M.; PHILLIPS, R.L. Genomic rearrangements in maize induced by tissue culture. Genome, v.29, p.122-128, 1987.

MURASHIGE, T.; SKOOG, F. A revised medium for rapid growth and bio assays with tobacco tissue cultures. Physiologia Plantarum, v.15, p.473-497, 1962.

MURRY, L.E.; ELLIOT, L.G.; CAPITANT, S.A.; WEST, J.A.; HANSON, K.K.; SCARAFIA, L.; JOHNSTON, S.; DELECAFLAHERTY, C.; NICHOLS, S.; CUNANAN, D.; DIETRICH, P.S.; METTLER, I.J.; DEWALD, S.; WARNICK, D.A.; RODES, C.; SINIBALDI, R.M.; BRUNKE, K.J. Transgenic corn plants expressing MDMV strain B coat protein are resistant to mixed infections of maize dwarf mosaic virus and maize chlorotic motle virus. Bio/Technology, v.11, p.1559-1564, 1993.

PRIOLI, L.M.; SILVA, W.J. Somatic embryogenesis and plant regeneration capacity in tropical maize inbreds. Revista Brasileira de Genética, v.12, p.553-566, 1989.

SANTOS, J.A. Estudo da instabilidade cromossômica em culturas de longa duração de calos de milho (Zea Mays L.). Piracicaba, 1995. 187p. Dissertação (Mestrado) - Escola Superior de Agricultura "Luiz de Queiroz", Universidade de São Paulo.
SANTOS, J.A.; AGUIAR-PERECIN, M.L.R. Chromosome instability in long-term maize callus cultures. Chromosome Research, v.3, p.60, 1995. Supplement. /Apresentado ao 12. International Chromosome Conference, Madri, Spain, 1995 Resumo/

SANTOS-SEREJO, J.A. Análise da transmissão e comportamento meiótico de cromossomos alterados em plantas de milho regeneradas in vitro e seleção de genótipos para cultura de calos com alta capacidade de regeneração. Piracicaba, 1999. 131p. Tese (Doutorado) - Escola Superior de Agricultura "Luiz de Queiroz", Universidade de São Paulo.

TOMES, D.T.; SMITH, O.S. The effect of parental genotype on initiation of embryogenic callus from elite maize (Zea mays L.) germplasm. Theoretical and Applied Genetics, v.70, p.505-509, 1985.

VASIL, V.; VASIL, I.K.; LU, C. Somatic embryogenesis in longterm callus cultures of Zea mays L. (Gramineae). American Journal of Botany, v.71, p.158-161, 1984.

WALTERS, D.A.; VETSCH, C.S.; POTTS, D.E.; LUNDQUIST, RC. Transformation and inheritance of a hygromycin phosphotransferase gene in maize plants. Plant Molecular Biology, v.18, p.189-200, 1992.

WAN, Y.; ROCHEFORD, T.R.; WIDHOLM, J.M. RFLP analysis to identify putative chromosomal regions involved in the anther culture response and callus formation of maize. Theoretical and Applied Genetics, v.85, p.360-365, 1992.

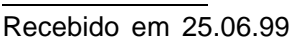

